\title{
Effect of Feeding Chandrasoor (Lipidium sativum L.) as Feed Supplement on Milk Yield in Indian Cows
}

\author{
Y.K. Naik, Ashwini Mugale*, M.A. Qureshi, R. Sahu and P.L. Choudhary \\ Department of Dairy Technology, College of Dairy Science and Food Technology, C.G.K.V., \\ Raipur, C.G.-492006, India \\ *Corresponding author
}

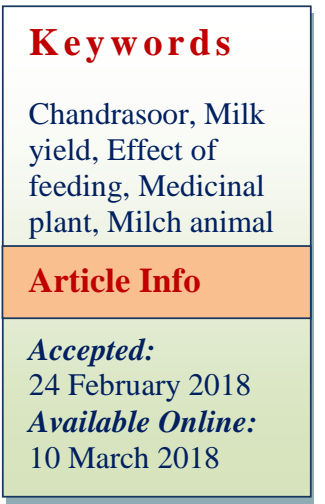

A B S T R A C T

This study was done to prepare a ration by supplement chandrasoor seeds and its performance in lactating animals then evaluate the effect of chandrasoor on the galactogogue activity in relation to milk yield and its major constituents. The entire feeding experiment was divided into three phases viz. Phase I, Phase II and Phase III and recorded the milk yield during the study. During Phase I, the cows in the respective groups were fed control rations namely - $\mathrm{T}_{1}, \mathrm{~T}_{2}, \mathrm{~T}_{3}, \mathrm{~T}_{4}, \mathrm{~T}_{5}$ and $\mathrm{T}_{6}$ for a period of 7 days (control period). During Phase II, the cows under the respective groups were put on the formulated concentrate ration having chandrasoor seed content of $0,100,150,200,250$ and $300 \mathrm{~g}$ in all treatments for the period of 7 days (treatment period). In Phase III, the cows under the respective groups were put again on control ration in all treatments rations for 45 days (residual period). During the experiment milk yield was recorded to observe the effect of chandrasoor containing ration on milk yield was highly significant i.e. 6.48, 6.62 and 7.20 liter/day in three phases of the study. Among all treatment $T_{5}$ is an appropriate dose of chandrasoor seed in which about 11 per cent milk yield was increased as compared to control. It was also observed that $\mathrm{T}_{5}(250 \mathrm{~g} / \mathrm{day})$ chandrasoor seed dose was more suitable then the other doses because the quantity of milk was improved significantly. Therefore, it could be concluded that supplementing lactating cows feed with chandrasoor seed is recommended as a new step in improving productive performance of the lactating cows, regarding milk yield.

\section{Introduction}

The importance of milk composition is appreciated by the consumers and producer for the quality and quantity of milk obtained from ideal feed management through addition of some feed additives/feed supplements in milch animal's rations. Several numbers of feed additives/ feed supplements were used as food ingredients; medicinal plants extracts, leaf, seed, root etc. are added in the standard ration. In view of this edible medicinal plant seeds such as chandrasoor (Lipidium sativum) seeds were used as feed supplement in ration of milch animals because this seed has galactogogue activity and used for treatment of other ailments such as stomach problem, indigestion, gas, eye problem, paralysis, bronchial asthma, inflammation, rheumatism, muscular pain, bleeding piles, leprosy, skin 
disease, diarrhea etc. and improve feed efficiency and performance of lactating cows (Salem and Elmahedy, 2001). Alternative growth promoters some of the medicinal plant such as Nigella sativa, Trigonella foenum and Lipidium sativum are generally used as feed supplement in lactating animals (Kholif and Abd El-Gawad, 2001; Abo El-Nor et al., 2007). Lipidium sativum contains principal components an alkaloidal form of lepidine (1, 3-dibenzyl-4, 5-dimethylimidazolium chloride named lepidiline A and 1, 3-dibenzyl-2, 4, 5trimethylimidazolium chloride named lepidiline B) have been identified which increases the Glunamic Pyrovate Transminace (Valentova and Ulrichova, 2003). Glunamic Oxaloacetate Transminace activities which increase the digestibility and nutrient assimilation, results for improving the galactogogue activity in lactating animals, when it is supplemented in the ration. The nutritional composition of fresh garden cress seedlings in per $100 \mathrm{~g}$ edible portion: water 89 g, energy $134 \mathrm{~kJ}$ (32 kcal), protein $2.6 \mathrm{~g}$, fat $0.7 \mathrm{~g}$, carbohydrate $5.5 \mathrm{~g}$, fibre $1.1 \mathrm{~g}, \mathrm{Ca} 81$ mg, Mg 38 mg, P 76 mg, Fe 1.3 mg, Zn 0.23 $\mathrm{mg}$, vitamin A $9300 \mathrm{IU}$, thiamin $0.08 \mathrm{mg}$, riboflavin $0.26 \mathrm{mg}$, niacin $1.0 \mathrm{mg}$, folate 80 $\mu \mathrm{g}$, ascorbic acid $69 \mathrm{mg}$ (USDA, 2002a).In addition, some studies indicated that the medicinal plants improved rumen activity and nutrient digestibility (El-Saadany et al., 1996; Aboul-Fotouh et al., 1999). Chandrasoor seed having a vital activity in man and animals as per the literature but no systematic study was carried out on its performance in lactating animals. Therefore, this study was carried out to evaluate the effect of chandrasoor on the galactogogue activity in relation to milk yield.

\section{Materials and Methods}

Feeding trial study on the animals was conducted at Jagannath Dairy, which is situated at Mana-road Temri. Samples were collected and analyzed the milk yield in the
Dairy Chemistry Laboratory, Department of Dairy Chemistry, College of Dairy Technology, Indira Gandhi Krishi Vishwavidyalaya, Raipur (Chhattisgarh). Chandrasoor seed have been used which was available in the local market was fed to the treatment group of the Indian cross breed cows.

The seeds of chandrasoor (Lipidium sativum L.) of commercial grade obtained from the local market of Raipur were subsequently used in this study. The nutritional composition of Chandrasoor seed given by USDA (2002a) is given in Table 1. From the herd 12 Indian cows of 4 to 8 years age and different stages of lactation were selected randomly. From selected cows, 6 groups were formed with 2 cows per group. The cows in each group were allotted in such a way that each cow have same yield i.e. $\mathrm{T}_{1}, \mathrm{~T}_{2}, \mathrm{~T}_{3}, \mathrm{~T}_{4}, \mathrm{~T}_{5}$ and $\mathrm{T}_{6}$ viz. 4 , 3, 4, 5, 6.5 and 8.5 liters/day, respectively. The cows were separately placed from the herd where feeding trials were conducted. Medical records were available for each cow and were observed routinely throughout the experiment by a veterinarian.

\section{Selection of feed and feed ingredients}

The animals were fed roughage and concentrate mixture separately. The concentrate mixture was offered to the animals twice a day i.e. during morning and evening milking. Feed given to the animals comprised of roughage and concentrate mixture.

The roughage was mainly green maize fodder, provided in the month of May and June They were fed $8 \mathrm{Kg}$ of green fodder and $4 \mathrm{~kg}$ of wheat straw during the period June -July. The quality of fodder was most of the time same to provide nutrients for maintenance requirement. For milk production an allowance of concentrated mixture compounded as in Table 2. 
Formulation of rations for cows under different treatments

Scheme for formulation of concentrate rations was on the concentration of chandrasoor seed formulated feeds. The formulated concentrate ration having chandrasoor seed are given in Table 3.

\section{Feeding schedule of lactating cows under different treatments}

Experimental rations (concentrate mixture) were fed to selected cows during the study as per the feeding schedule. They were fed $8 \mathrm{Kg}$ of green fodder and $4 \mathrm{Kg}$ of wheat straw during the period May-June. The quality of fodder was most of the time same to provide nutrients for maintenance requirement. For milk production an allowance of concentrated mixture compounded with -Crushed grain (maize/barley) -25 Percent, GNC/or other Oil cakes -30 Percent, Wheat bran/Rice bran 42 Percent, Mineral mixture 2 Percent and common salt 1 Percent were fed/ day per animal, respectively, during the experimental period.

Normal Feed of the experimental animals (Cows) Milk yield was recorded daily. Samples of feed were analyzed for proximate composition using the methods described in A.O.A.C. (1990). The data obtained during the experiment were analyzed using split-plot design described by Snedecor and Cochran (1994).

\section{Results and Discussion}

During the course of investigation many interesting and useful facts were observed through regular monitoring of milk yield.

\section{Effect of chandrasoor seed supplemented ration on Milk Yield}

The ration were prepared using different proportion such as $0\left(\mathrm{~T}_{1}\right), 100\left(\mathrm{~T}_{2}\right), 150\left(\mathrm{~T}_{3}\right)$, $200\left(\mathrm{~T}_{4}\right), \quad 250 \quad\left(\mathrm{~T}_{5}\right)$ and $300 \quad\left(\mathrm{~T}_{6}\right) \mathrm{g}$ of chandrasoor seed. The ration was fed to treatment group for seven days. The milk drawn and recorded at both the milking time of each groups under the treatment $\left(\mathrm{T}_{1}, \mathrm{~T}_{2}, \mathrm{~T}_{3}\right.$, $\mathrm{T}_{4}, \mathrm{~T}_{5}$ and $\mathrm{T}_{6}$ ) in all the three phases of the experiments was given in Table 4 .

The result given in Table 2 indicates that in phase I average quantity for milk yield of different treatments $\left(\mathrm{T}_{1}, \mathrm{~T}_{2}, \mathrm{~T}_{3}, \mathrm{~T}_{4}, \mathrm{~T}_{5}\right.$ and $\left.\mathrm{T}_{6}\right)$ were $3.99,3.04,4.02,5.02,6.48$ and 8.50 lit/day, respectively, whereas in phase II the milk yield was found to be $3.99,3.04,4.08$, $5.08,6.62$ and $8.54 \mathrm{lit} /$ day, respectively during 7 days treatment period. Subsequently, after withdrawal of experimental ration values of milk yield was recorded and were found to be 3.99, 3.31, 4.46, 5.59, 7.20 and $8.83 \mathrm{lit} / \mathrm{day}$, respectively in all the treatments.

Table.1 Nutritional composition of Chandrasoor seed given by USDA (2002a)

\begin{tabular}{|c|l|l|}
\hline S. No. & Constituents & Edible portion \\
\hline 1 & Water & $89 \mathrm{~g} / 100 \mathrm{~g}$ \\
\hline 2 & Energy & $134 \mathrm{~kJ}(32 \mathrm{kcal}) / 100 \mathrm{~g}$ \\
\hline 3 & Protein & $2.6 \mathrm{~g} / 100 \mathrm{~g}$ \\
\hline 4 & Fat & $0.7 \mathrm{~g} / 100 \mathrm{~g}$ \\
\hline 5 & Carbohydrate & $5.5 \mathrm{~g} / 100 \mathrm{~g}$ \\
\hline 6 & Fiber & $1.1 \mathrm{~g} / 100 \mathrm{~g}$ \\
\hline 7 & $\mathrm{Ca}$ & $81 \mathrm{mg} / 100 \mathrm{~g}$ \\
\hline 8 & $\mathrm{Mg}$ & $38 \mathrm{mg} / 100 \mathrm{~g}$ \\
\hline 9 & $\mathrm{P}$ & $76 \mathrm{mg} / 100 \mathrm{~g}$ \\
\hline
\end{tabular}


Table.2 Normal feed of the experimental animals (Cows)

\begin{tabular}{|c|l|c|}
\hline S. No. & Ingredients & Quantity (\%) \\
\hline 1 & Grains (maize/barley) & 25 \\
\hline 2 & GNC/Other oil cake & 30 \\
\hline 3 & Wheat bran/Rice bran & 42 \\
\hline 4 & Mineral mixture & 2 \\
\hline 5 & Salt & 1 \\
\hline
\end{tabular}

Table.3 Formulated concentrate ration supplementing Chandrasoor seed content in different treatment groups

\begin{tabular}{|c|c|c|}
\hline S. No. & Treatments Groups & Chandrasoor seed content $(\mathbf{g})$ \\
\hline 1 & $\mathrm{~T}_{1}($ Control $)$ & 0 \\
\hline 2 & $\mathrm{~T}_{2}$ & 100 \\
\hline 3 & $\mathrm{~T}_{3}$ & 150 \\
\hline 4 & $\mathrm{~T}_{4}$ & 200 \\
\hline 5 & $\mathrm{~T}_{5}$ & 250 \\
\hline 6 & $\mathrm{~T}_{6}$ & 300 \\
\hline
\end{tabular}

Table.4 Effect of different level of Chandrasoor seed in feed on milk yield (lit/day) of cows in three phases of the experiment

\begin{tabular}{|c|c|c|c|c|c|c|}
\hline \multirow[t]{2}{*}{ Phases } & \multicolumn{6}{|c|}{ Different levels of chandrasoor seed } \\
\hline & $\mathbf{T}_{1}$ & $\mathbf{T}_{2}$ & $\mathbf{T}_{3}$ & $\mathbf{T}_{4}$ & $\mathbf{T}_{5}$ & $\mathbf{T}_{6}$ \\
\hline $\mathbf{P}_{1}$ & 3.99 & 3.04 & 4.02 & 5.02 & 6.48 & 8.50 \\
\hline$\overline{\mathbf{P}_{2}}$ & 3.99 & 3.04 & 4.08 & 5.08 & 6.62 & 8.54 \\
\hline $\mathbf{P}_{3}$ & 3.99 & 3.31 & 4.46 & 5.59 & 7.20 & 8.83 \\
\hline Pooled & 3.99 & 3.13 & 4.19 & 5.23 & 6.77 & 8.62 \\
\hline
\end{tabular}

Table.5 Effect of different level of Chandrasoor seed in feed on milk yield (lit/day) of cows among three phases of the experiment

\begin{tabular}{|c|c|c|c|c|c|c|}
\hline \multirow{2}{*}{$\begin{array}{c}\text { Phases } \\
\text { Differences }\end{array}$} & \multicolumn{6}{|c|}{ Different levels of Chandrasoor seed } \\
\hline & $\mathrm{T}_{1}$ & $\mathrm{~T}_{2}$ & $\mathrm{~T}_{3}$ & $\mathrm{~T}_{4}$ & $\mathrm{~T}_{5}$ & $\mathrm{~T}_{6}$ \\
\hline $\mathbf{P}_{2}(-) \mathbf{P}_{1}$ & 0.00 & 0.00 & 0.06 & 0.06 & 0.14 & 0.14 \\
\hline $\mathbf{P}_{3}(-) \mathbf{P}_{2}$ & 0.00 & 0.27 & 0.38 & 0.51 & 0.58 & 0.29 \\
\hline $\mathbf{P}_{3}(-) \mathbf{P}_{1}$ & 0.00 & 0.27 & 0.44 & 0.57 & 0.72 & 0.33 \\
\hline
\end{tabular}


To evaluate the effect of ingestion of different level of chandrasoor seeds, milk yield of individual cows under phase $\mathrm{I}$ as well as under different treatments were monitored throughout the experiment. The detail phase wise data for the milk yield during treatment phase II and residual phase III in the summer season presented in Table 4, whereas the average data of milk yield of the cows under various treatment within the phases $\left[\mathrm{P}_{2}(-) \mathrm{P}_{1}\right.$, $\mathrm{P}_{3}(-) \mathrm{P}_{2}$ and $\left.\mathrm{P}_{3}(-) \mathrm{P}_{1}\right]$ presented in Table 3.

The data are average of milk yield of the treatments during the phases I ( 7 days), II (7 days) and III (45 days). The result indicates that there was significant effect on milk yield with respect to level of ingestion of chandrasoor containing ration. In order to examine overall effect of feeding chandrasoor containing ration at different levels on milk yield of the experimental cows was presented in Table 5 and found that differences among the three phases are $\mathrm{P}_{2}(-) \mathrm{P}_{1}, \mathrm{P}_{3}(-) \mathrm{P}_{2}$ and $\mathrm{P}_{3}(-)$ $\mathrm{P}_{1}$ under the treatments $\left(\mathrm{T}_{1}, \mathrm{~T}_{2}, \mathrm{~T}_{3}, \mathrm{~T}_{4}, \mathrm{~T}_{5}\right.$ and $\left.\mathrm{T}_{6}\right)$ are found $(0.00,0.00,0.06,0.06,0.14$ and $0.04),(0.00,0.27,0.38,0.51,0.58$ and 0.29$)$ and $(0.00,0.27,0.44,0.57,0.72$ and 0.33$)$ respectively. The results indicated that there is significant $(\mathrm{P}>0.05)$ effect on milk yield of the experimental cows. Similarly, when the average value/pooled value on milk yield of these animals compared with respect to three different phases was somewhat closer to each other within the treatments except $\mathrm{T}_{5}$ and $\mathrm{T}_{4}$ in which it was observed that there was increase in milk yield significantly it may be due to the effect of chandrasoor seed dose as fed with ration.

Milk yield was a major constraint of the study and it was observed throughout the study under same experimental conditions as adopted for evaluating the dose chandrasoor seed used as feed supplement and fed for 7 days (Treatment period). The milk yield was recorded during the study and found that the milk yield was increased significantly in $T_{5}$ (0.72 liter/day) as compared to control and $\mathrm{T}_{2}$, $\mathrm{T}_{3}, \mathrm{~T}_{4}$, and $\mathrm{T}_{6}(0.27,0.44,0.57$ and 0.33$)$ liter/day, respectively. The increase in milk yield may be due to gradual improvement in the digestive system, repairing of internal injury occurs after parturition as per the physical observation of the animal before and after the treatment.

\section{References}

A.O.A.C. (1990). Association of Official Analytical Chemists, Official Method of Analysis, $15^{\text {th }}$ ed. 22 Wilson Boulevard, Arlington Virginia, USA.

Abo, El-Nor, S. A. H, Khattab, H. M., AlAlami, H. A., Salem, F. A. and Abdou, M. M. (2007) Effect of some medicinal plants seeds in the ration on the productive performance of lactating buffaloes. Inter. J. Dairy Sci., 2(4): 348355.

Aboul-Fotouh, G. E., Allam, S. M., Shehata, E. I. and Abd El-Azeem, S. N. (1999) Effect of some medicinal plants as feed additives on performance of growing sheep. Egyptian J. Nutri. Feed, 2:79.

El Saadany, S. A., Abdel-Mimia, M., AboAmmou, F. F. and Shehata, E. (1996) Effect of Using Medicinal Herbs as Milk Stimulent Feed Supplementation on ewes and lambs performance. Egyptian J. Appl. Sci., 11: 41.

Kholif, A. M. and Abd El Gawad, M. A. M. (2001) Medicinal plant seeds supplementation of lactating goat's diets and its effects on milk and cheese quantity and quality. Egyptian J. Dairy Sci., 29(1): 139-150.

Salem, F. A. and El-Mahdy, M. R. (2001) Effect of some medicinal plants as feed additives on nutrients digestibility, rumen fermentation, blood and carcass characteristics of sheep. $2^{\text {nd }}$ Conference 
Animal Production Health Semi-Arid Area.

Snedecor, G. W. and Cochran, W. G. (1994) Statistical methods. Affiliated EastWest press Pvt. Ltd., New Delhi, pp. 466-490.

USDA (2002a) USDA nutrient database for standard reference. Release 15. [Internet] U.S. Department of
Agriculture, Beltsville Human Nutrition Research Centre, Beltsville MD, United State.

Valentova, K. and Ulrichova, J. (2003) Smallanthus sonchifolius and Lepidium meyenii prospective medicinal crops for the prevention of chronic diseases. Published in Biomed. Papers 147(2): 119-130.

\section{How to cite this article:}

Naik, Y.K., Ashwini Mugale, M.A. Qureshi, R. Sahu and Choudhary, P.L. 2018. Effect of Feeding Chandrasoor (Lipidium sativum L.) as Feed Supplement on Milk Yield in Indian Cows. Int.J.Curr.Microbiol.App.Sci. 7(03): 2946-2951. doi: https://doi.org/10.20546/ijcmas.2018.703.340 